\title{
Web-Based Library Service Information System Design Using Electronic Customer Relationship Management (E-CRM) At SMK YUPPENTEK 1 Tangerang
}

\author{
Ita Erliyani $^{* 1}$, Widya Safitri ${ }^{2}$, Tobi Nurhidayat ${ }^{3}$ \\ ${ }^{1,2,3}$ Information System Study Program, Raharja University Faculty of Science and \\ Technology \\ E-mail: " ${ }^{1}$ ita.erlivani@ raharia.info, ${ }^{2}$ widya.safitri@ raharja.info. \\ tobi.nurhidayat@raharja.info
}

\begin{abstract}
The utilization of information and communication technology in education is a means of informing quality education. One area that feels the impact of technology in the library. SMK Yuppentek 1 Tangerang currently has a library, but it is not computerized with an information system. In other words, all data is still written in a ledger to recapitulate the transactions that occur so that the data is less accurate in the reporting process. The collection of books that is continually increasing in the library is not followed by the readiness of the officers to update the data so that it becomes difficult for visitors to get the latest information. This study aims to create a website-based library information system at SMK Yuppentek 1 Tangerang city by using Electronic Customer Relationship Management (E$C R M)$ as a service improvement strategy that is oriented to the needs of members so that it becomes a solution for processing library information data to be practical, accurate and effective. Easy and excellent service can be obtained by visitors well. The methodology of this research analysis is the method of data collection and analysis of Performance, Information, Economic, Control, Efficiency, Service (PIECES), which will present a discussion of the theoretical basis, stages of analyzing and modeling processing systems using Unified Modeling Language (UML), black-box testing that will be used as a testing method.
\end{abstract}

Keywords - Web-Based Library, Electronic Customer Relationship Management (E-CRM), Black-Box Testing

\section{INTRODUCTION}

One application of technology in the field of education is the application in the library. As an information processing institution for library materials, the library is a field that applies information technology to develop more advanced. The development of types of libraries indicates the development of the application of information technology, initially manual libraries, automated libraries, digital libraries, and e-libraries. Given the rapid development of technology and information, the library is trying to use an Electronic Customer Relationship Management (E-CRM)-a based library which is expected to provide different services for library users in the school environment. The expected quality of service can be achieved. ECRM is a strategy for using information technology that gives libraries a perception of library users: students, teachers, students, and the wider community, which can be relied on and interacted with; thus, all mechanisms and customer interactions help maintain reading interest and mutually beneficial relationships ${ }^{[1]}$. 
Researchers see the problems that exist in the Yuppentek 1 Tangerang Vocational High School library in the application of their activities are still not integrated with the computer system so that all process activities are still carried out manually, making the librarian's performance less than optimal, one example is the book search system that spends a lot of time, there was a data error due to his undisciplined in borrowing and returning books recorded in the books. This makes the service to students and teachers less than optimal. The researcher first conducts a system analysis by parsing several parts and.

\section{RESEARCH METHOD}

\section{A. Analysis Method}

The data was analyzed using the PIECES analysis method to identify problems, so performance, information, control, efficiency, and service must be analyzed [3].

Table 1. Table of Identification of Running Systems Using the PIECES Method

\begin{tabular}{|c|c|c|}
\hline Analysis & \multicolumn{2}{|c|}{ Running System } \\
\hline Performance & $\begin{array}{l}\text { Long collection searches and } \\
\text { calculations slow down the } \\
\text { performance process. }\end{array}$ & $\begin{array}{l}\text { The amount of workload that } \\
\text { exceeds the reporting process. }\end{array}$ \\
\hline Information & $\begin{array}{l}\text { There are no systematic reports on } \\
\text { the number of books, transaction } \\
\text { data on borrowing and returning, } \\
\text { which slows down decision making }\end{array}$ & $\begin{array}{l}\text { Inaccurate information about } \\
\text { the types of library } \\
\text { collections, not all available } \\
\text { collections are inventoried. }\end{array}$ \\
\hline Economy & $\begin{array}{l}\text { The recording of book borrowing } \\
\text { and the calculation of late fees are } \\
\text { not recorded properly, so there is a } \\
\text { loss. }\end{array}$ & Increased operating costs \\
\hline Security & $\begin{array}{l}\text { Data loss occurs, there is no good } \\
\text { data backup }\end{array}$ & $\begin{array}{l}\text { There is no protection against } \\
\text { data that has been recorded } \\
\text { manually. }\end{array}$ \\
\hline efficiency & Report generation takes a long time. & $\begin{array}{l}\text { Existing computers are only } \\
\text { used to do correspondence; a } \\
\text { lot of paper is used to input } \\
\text { data. }\end{array}$ \\
\hline service & $\begin{array}{l}\text { Lack of excellent service creation } \\
\text { because the library does not have an } \\
\text { audio collection }\end{array}$ & $\begin{array}{l}\text { visual The data is not well } \\
\text { organized, so to get two } \\
\text { information in processing, } \\
\text { you have to search all the } \\
\text { files that are not organized }\end{array}$ \\
\hline
\end{tabular}


Table 2. The following is a PIECES matrix table to find the best opportunities for the system to be built

\begin{tabular}{|c|c|c|}
\hline Analysis & \multicolumn{2}{|c|}{ Design } \\
\hline Performance & $\begin{array}{l}\text { E-resource feature to make it easier for } \\
\text { users to get information on book } \\
\text { collections. }\end{array}$ & $\begin{array}{l}\text { The data will be stored in a } \\
\text { database that will be integrated } \\
\text { with the system }\end{array}$ \\
\hline Information & $\begin{array}{l}\text { The system is equipped with reports } \\
\text { that will be tailored to the needs of } \\
\text { each user }\end{array}$ & $\begin{array}{l}\text { E-resource feature that will } \\
\text { provide information. }\end{array}$ \\
\hline Economy & $\begin{array}{l}\text { The system for recording the } \\
\text { availability of books and borrowing } \\
\text { books as well as late fees for returning } \\
\text { books makes it easier to report } \\
\text { operational costs }\end{array}$ & \\
\hline Security & $\begin{array}{l}\text { The system is designed to use a } \\
\text { database and can back up data }\end{array}$ & $\begin{array}{l}\text { There is a login menu, which } \\
\text { the user can only access. And } \\
\text { make those who are not } \\
\text { concerned can not access the } \\
\text { data }\end{array}$ \\
\hline Efficiency & $\begin{array}{l}\text { Computerized making it easier to make } \\
\text { reports }\end{array}$ & \\
\hline Service & $\begin{array}{l}\text { make it easier to record reports and } \\
\text { search data does not take long }\end{array}$ & $\begin{array}{l}\text { Data is organized by going up } \\
\text { in the system }\end{array}$ \\
\hline
\end{tabular}

\section{B. Design Method}

The stages of system design are adjusted to the needs and objects being studied. This research design method uses the Unified modeling language (UML) to draw visually. The software uses an "object-oriented" paradigm using actual modeling to simplify complex problems to be easy to understand and learn ${ }^{[4]}$. The system design uses Visual studio code to process syntax, the Personal Homepage (PHP) programming language, and the MySQL database interface (Structure Query Language), namely PHP MyAdmin. 


\section{Use Case Diagram of Running System}

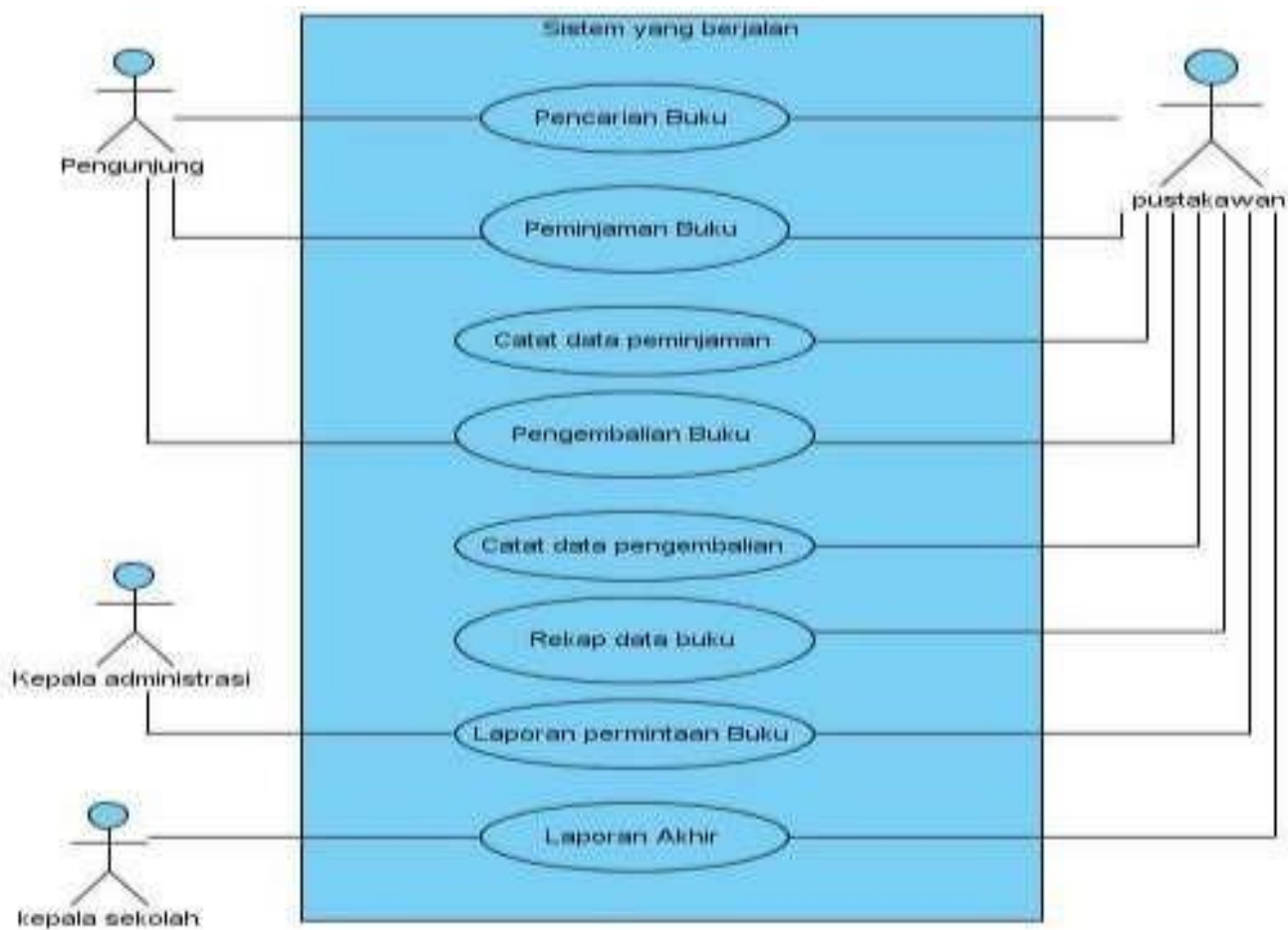

Figure 1. Use Case Diagram of the Running System

Actors who interact with the system are visitors (teachers, students), administration heads, principals, and librarians. Visitors search, borrow and return books to be processed by librarians, and librarians record loans and record returns for librarians and make reports that will be given to the head of administration and school principal.

\section{Literature Review}

1) Siti Nurajizah conducted this research in 2019 entitled "Implementation of Web-based E-CRM in the Gema Nurani School Digital Library." which can be input for library managers. In the system that I will design, it will contain features consisting of a search menu for book collections, guest books, library membership lists that can be accessed by yourself, borrowing books in pdf and print form, compiling reports, and a reminder feature for books that must be returned. ${ }^{[5]}$

2) Research by Cahyani Budihartanti, Tuslaela, and Elok Nur Aeni in 2019 with the title "Online Library Information System (E-Library) at MTS Al-Maghfiroh Pekayon" This study describes the e-library information system at MTs Al-Maghfiroh to facilitate library members and librarians through the use of the internet so that it is easy for members to view data quickly, even though members do not directly visit the library, from internet access all information related to various book data can be seen, even book lending can be done online anytime and anywhere through the most updated data. The system that I will design will contain features consisting of a search menu for book collections, guest books, library membership lists that can be accessed by yourself, borrowing books in pdf and print form, compiling reports, and a reminder feature for books that must be returned. ${ }^{[6]}$

3) Research by Lily W, et al. in 2017 entitled "User Requirements Analysis For Digital Library Application Using Quality Function Deployment." This study describes the efforts to build a Smart Digital Library to be used by the wider community wherever they are. This system is built in a Smart Digital Library portal that uses the Semantic Similarity method to search for journals, articles, or books with the title or author's name. This method is also used to determine the recommended books for visitors to the 
Smart Digital Library to read. In the system that I will design, it will contain features consisting of a search menu for book collections, guest books, library membership lists that can be accessed by yourself, borrowing books in pdf and print form, compiling reports, and a reminder feature for books that must be returned. ${ }^{[7]}$

4) This research was conducted by Hadi Rahadian and Gandug Triyono in 2018 entitled "Design of an Object-Based Library Information System at SMAN 33 Jakarta". It can be calculated automatically. The system that I will design will contain features consisting of a search menu for book collections, guest books, library membership lists that can be accessed by yourself, borrowing books in pdf and print form, compiling reports, and a reminder feature for books that must be returned. ${ }^{[8]}$

5) Research by Esfimal M, et al. in 2018 entitled "Library Management Information System With Barcodes at GKI Gunung Sahari Jakarta." VB.NET. The system that I will design will contain features consisting of a search menu for book collections, guest books, library membership lists that can be accessed by yourself, borrowing books in pdf and print form, compiling reports, and a reminder feature for books that must be returned. ${ }^{[9]}$

\section{RESEARCH RESULTS AND DISCUSSION}

In this study, create and design a digital library service website equipped with a selfregistration feature to record members well. And input, data storage, and report generation can be done quickly. With the simplification and improvement of the current system, handling the activities will be easier and more efficient. The proposed design will be illustrated with sequence, use case, class, and activity diagrams.

\section{Use Case Diagram of the Proposed System}

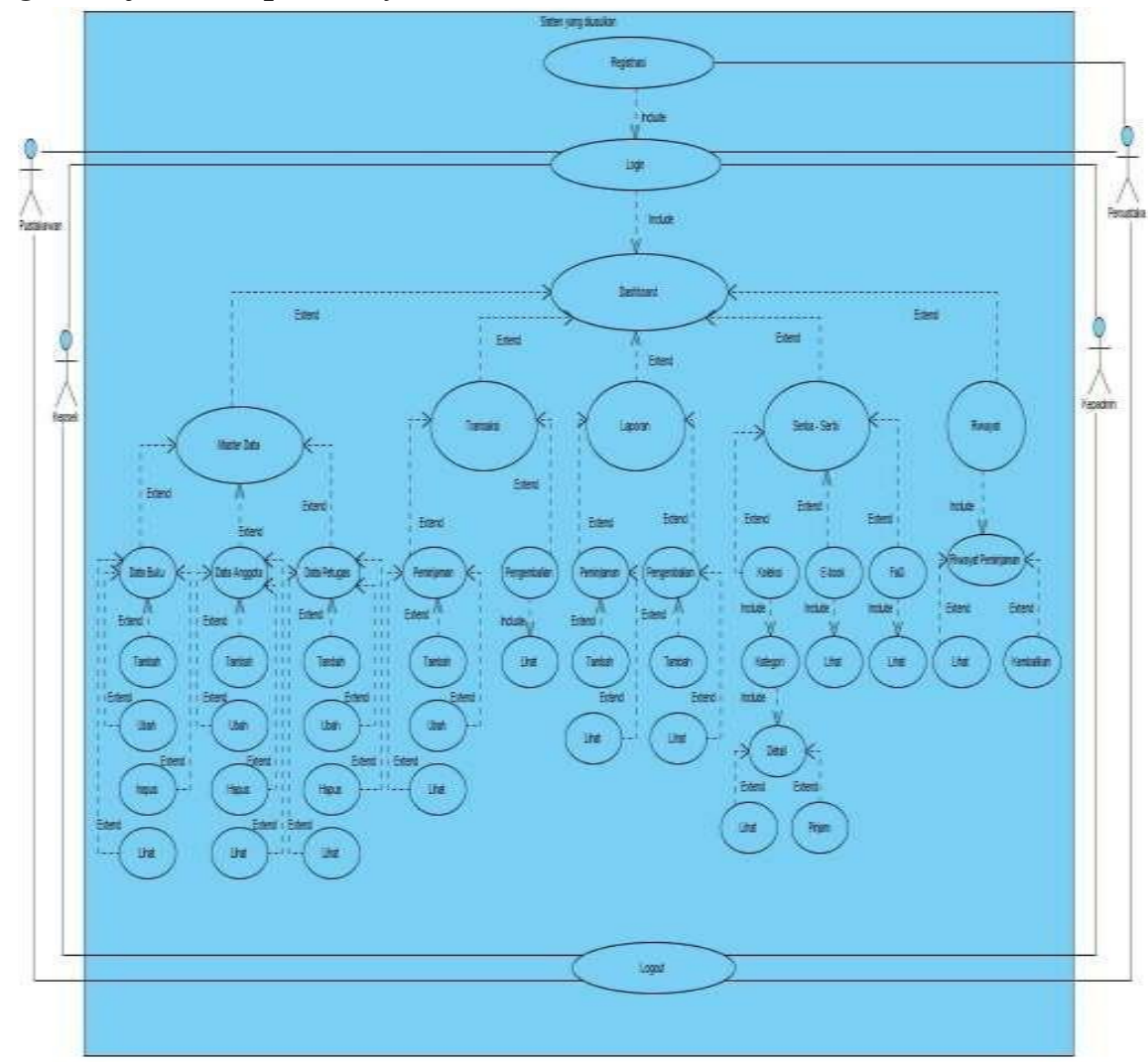

Figure 2. Use Case Diagram of the Proposed System 
The conclusion from the picture above:

The user must register first before logging in; the user can see several menus, including the dashboard, sundries, history. Librarians, principals, and head admins must log in before entering the website. The dashboard librarian can access the menu, master data, transactions, reports, and principals, and chief admins can only access the dashboard and report menus.

Design the propose website Perpustakaan SMK 1 Yuppentek

1. Login Page Display

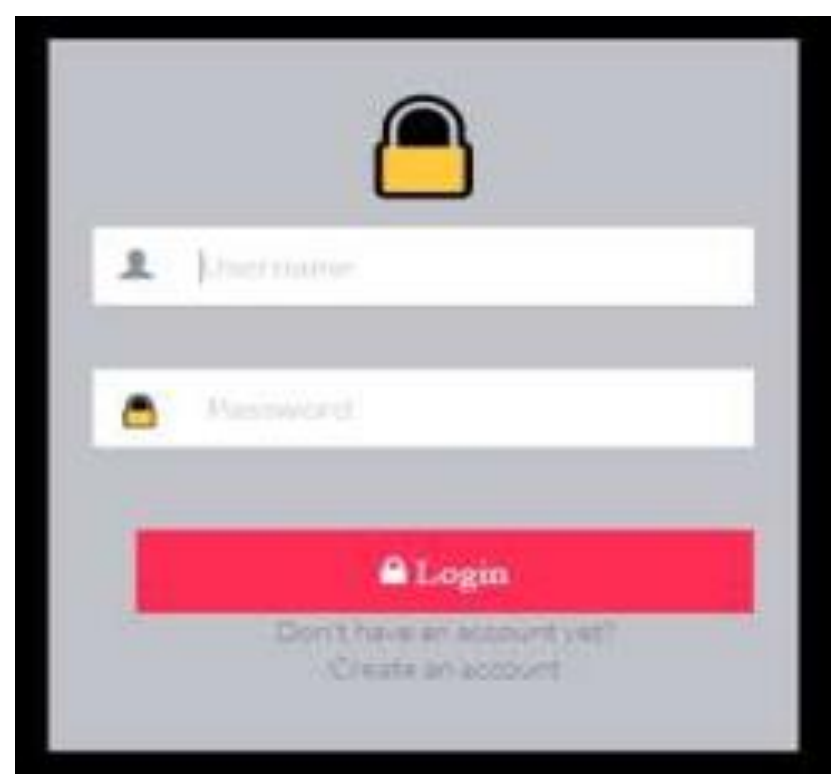

Figure 3. Login page

2. Member Registration Page Display

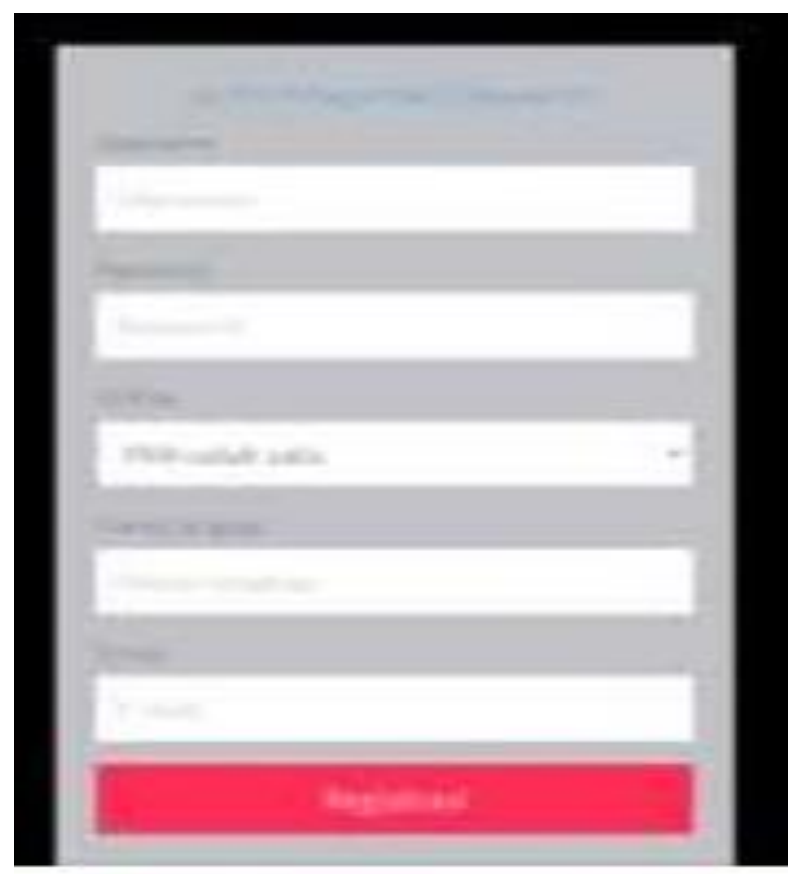

Figure 4. Member Registration Page 
3. Dashboard Page View

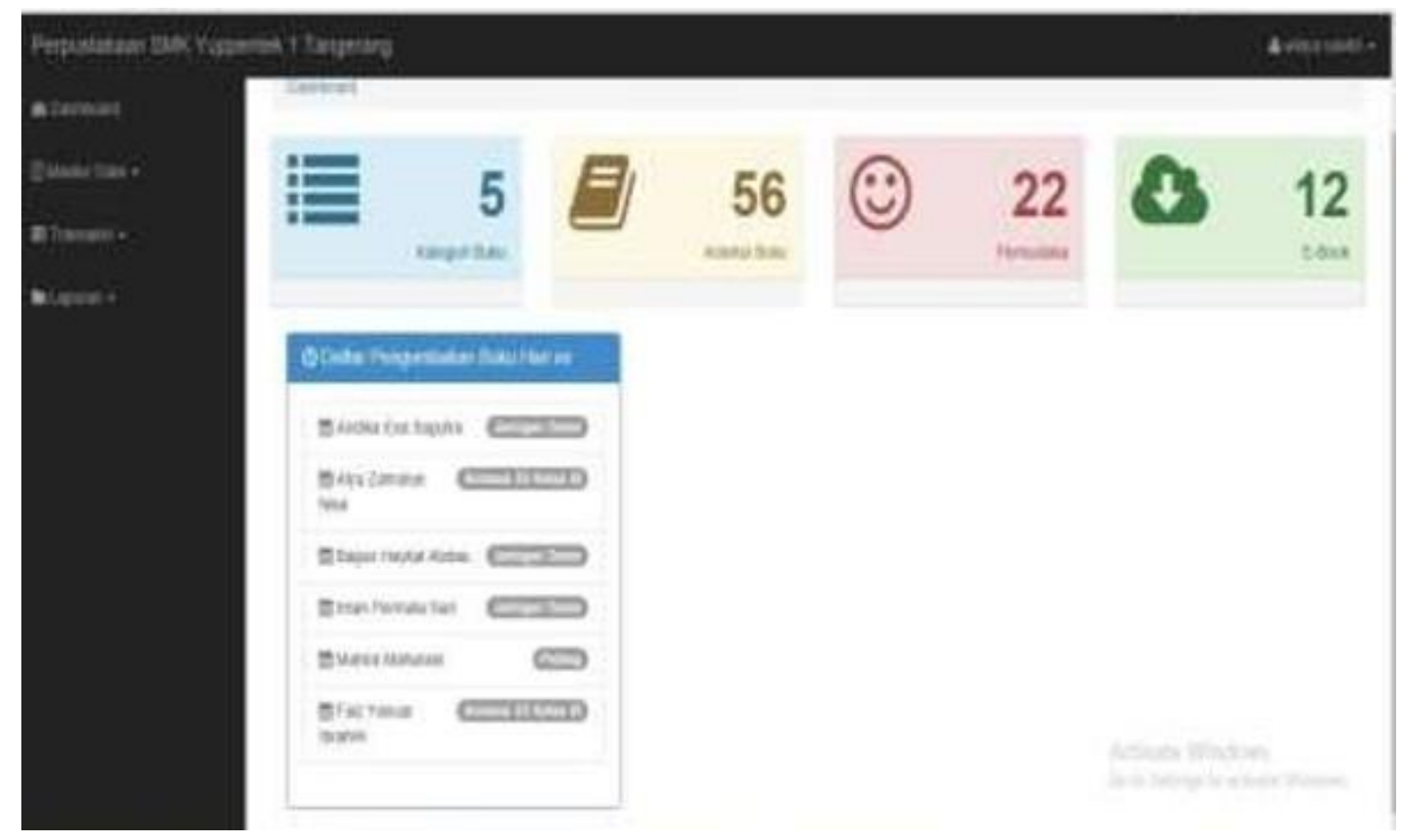

Figure 5. Dashboard page

4. Book Data Master Page Display

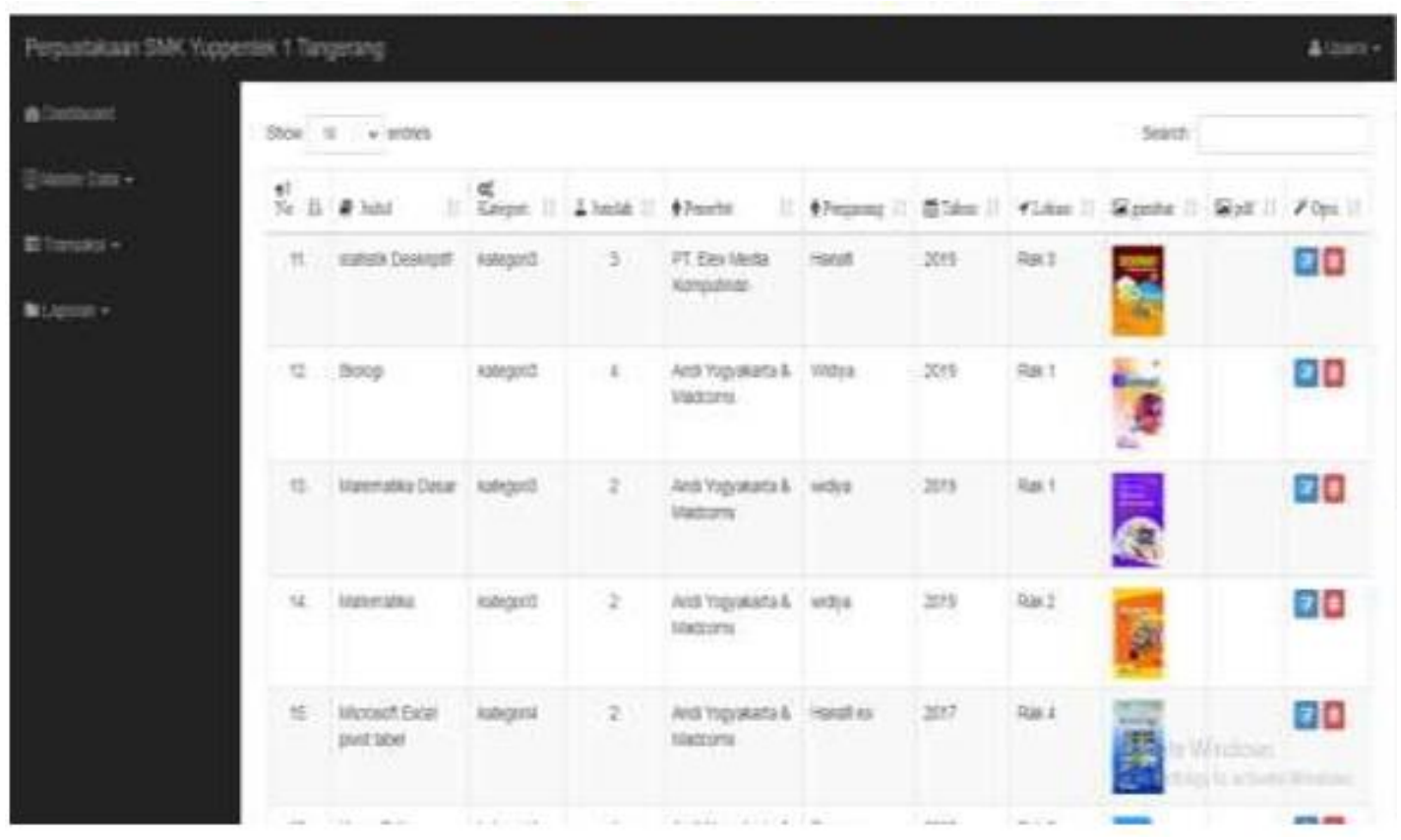

Figure 6. Book Data Master Page 
5. Loan Transaction Page Display

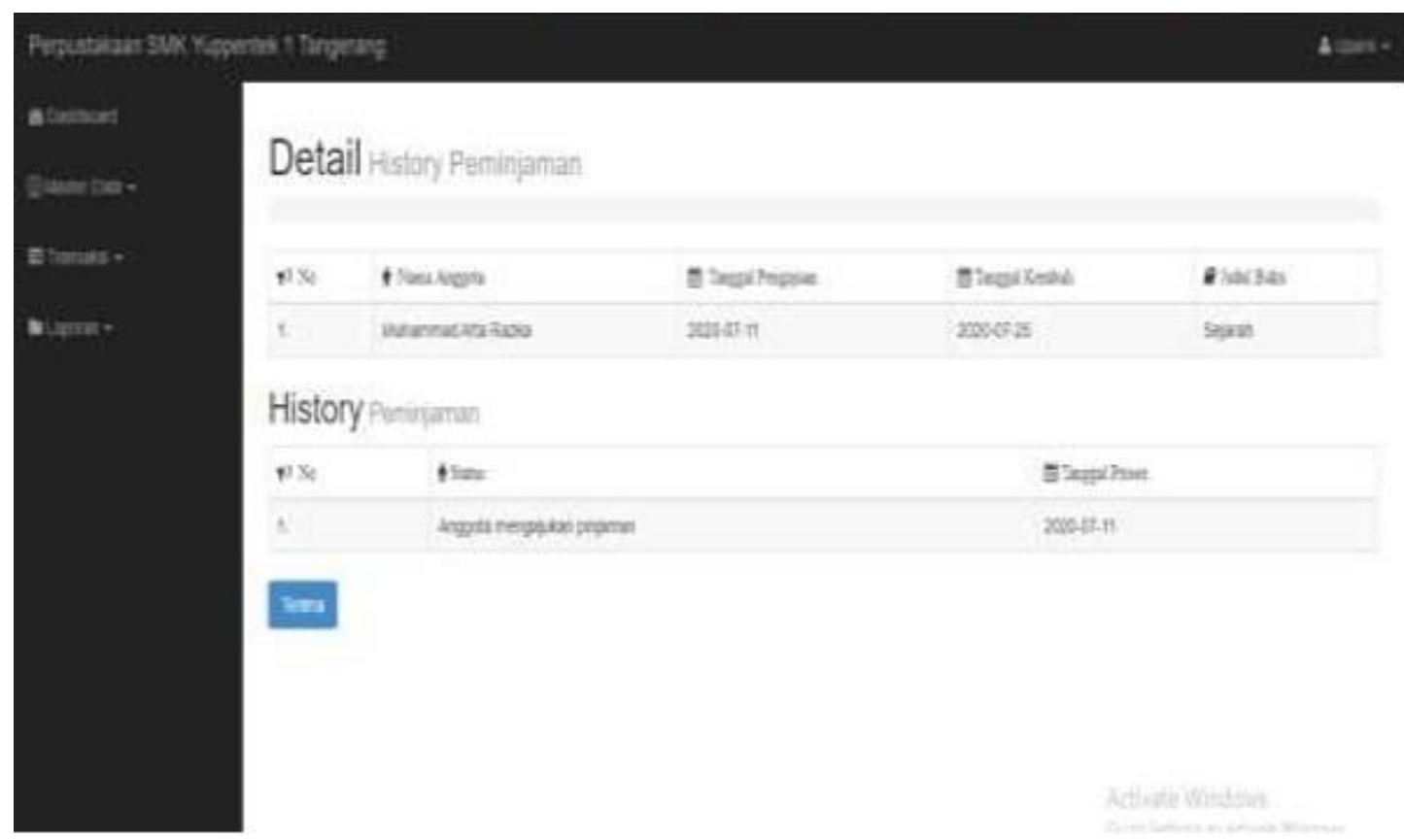

Figure 7. Loan Transaction Page

6. Return Transaction Page Display

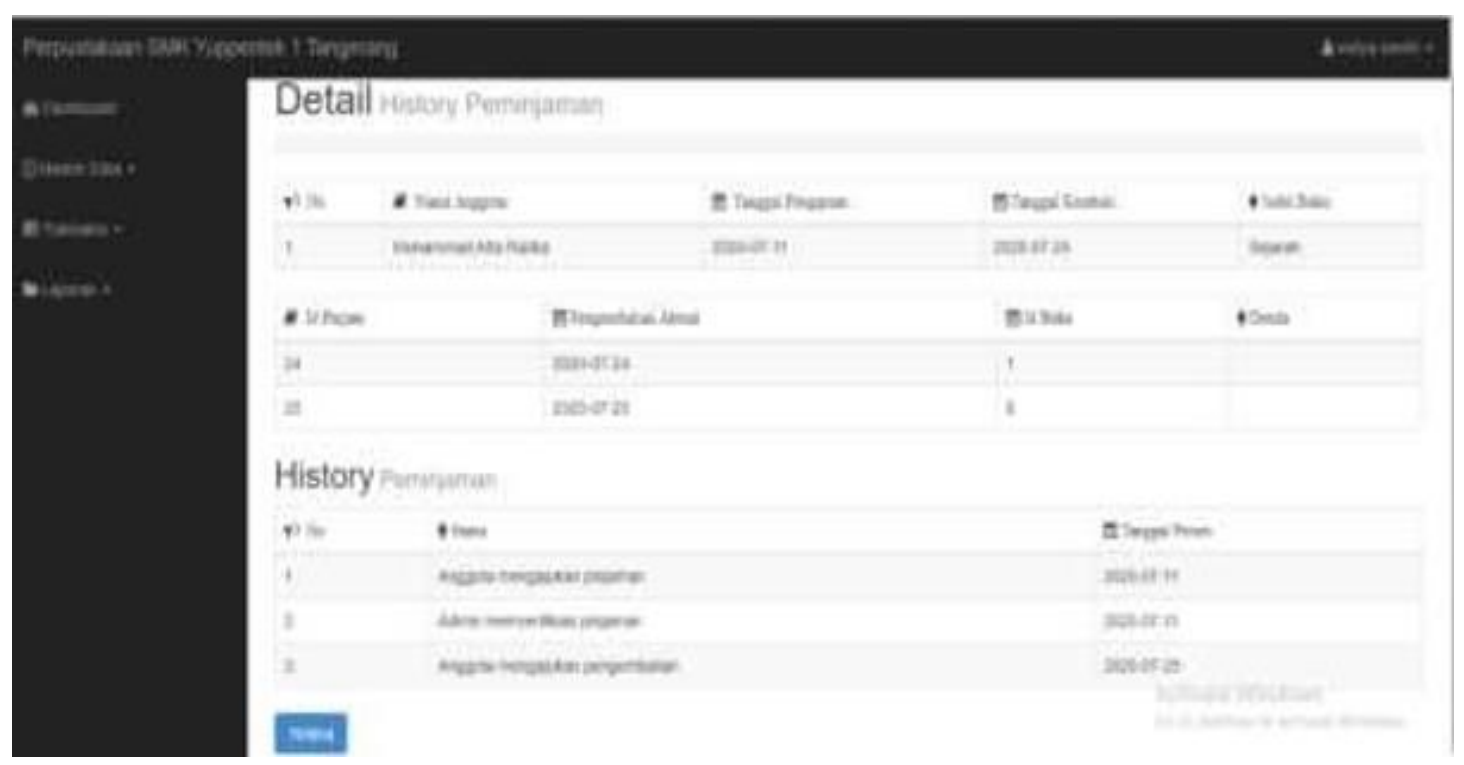

Figure 8. Return Transaction Page 
7. Report Page View
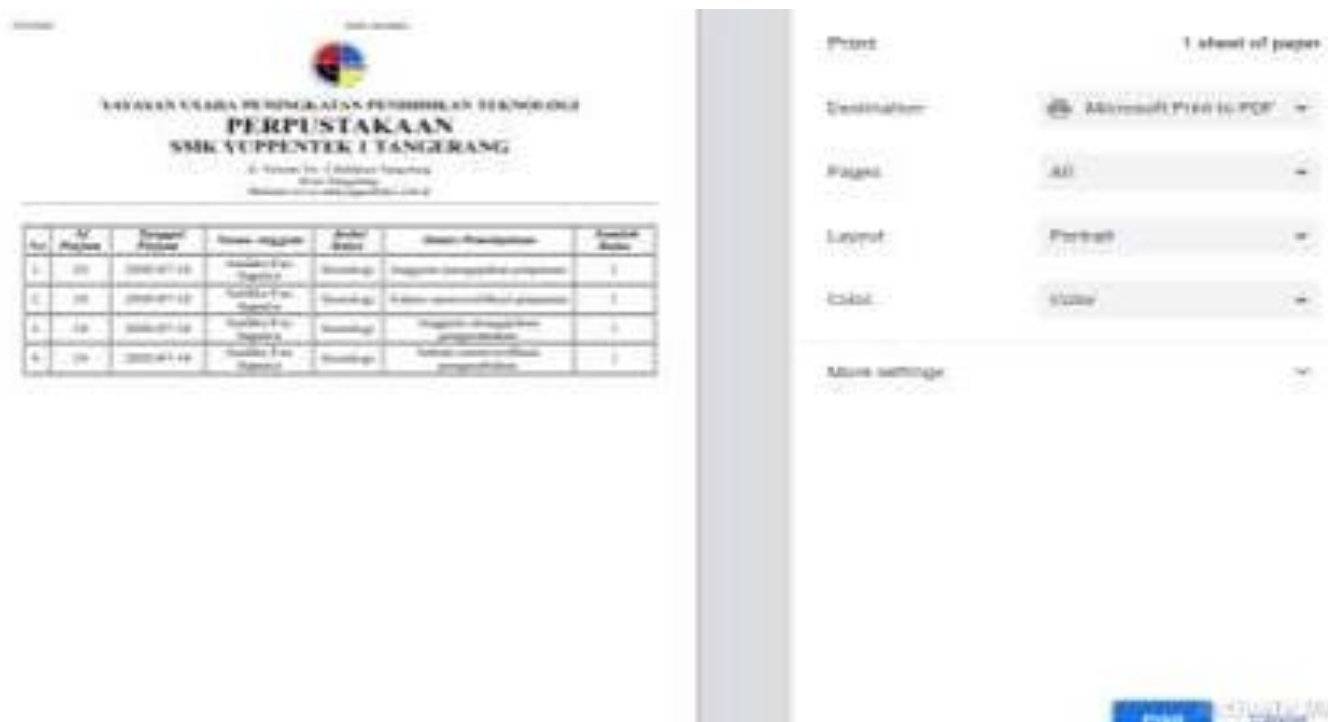

Figure 9. Report page

\section{CONCLUSION}

Based on the analysis of the problems that occur in the library of SMK 1 Yuppentek are:

1) Data collection of existing members, books, and transactions is still semi-manual using Microsoft Office Excel and paper programs.

2) It takes a long time to record, search for member data, transactions and in making reports

3) The library website can facilitate activities in the library, and data can be stored in a well-organized manner to deliver information quickly.

\section{SUGGESTED}

1) Librarians are expected to be able to update the collection of books on the library website

2) It is expected that the storage of printed book collections is always adjusted to the book data on the system.

3) Librarians routinely perform data backups to maintain the system.

\section{REFERENCES}

[1] Budihartanti, C., dkk.(2019). Sistem Informasi Perpustakaan Online (E-Library) Pada MTS Al-Maghfiroh Pekayon, STMIK Nusa Mandiri. Jurnal Ilmu Pengetahuan dan Teknlogi Komputer, IV (2).

[2] Maimunah, dkk. 2017. "Aplikasi Sistem Order Online Berbasis Mobile Android pada Outlet Pizza Hut Delivery”. Jurnal Semnas Teknomedia Online, Volume V, Nomor 1 (2017). 
[3] Malau, E., dkk. (2018). Sistem Informasi Manajemen Perpustakaan Dengan Barcode Di GKI Gunung Sahari Jakarta. BINA INS ANI ICT JOURNAL, Volume V, Nomor 1.

[4] Muslihudin, M., dan Oktofianto. (2016). Analisa dan Perancangan Sistem Informasi Menggunakan UML dan Model Terstruktur. Jogjakarta, Indonesia: Penerbit Andi.

[5] Nurajizah, Siti. (2019). Implementasi E-CRM berbasis Web pada Perpustakaan Digital Sekolah Gema Nurani. Jurnal Sistem Informasi dan Teknik Informatika. Volume IX Nomor 1.

[6] Nurajizah, Siti. (2019). Implementasi E-CRM berbasis Website pada Perpustakaan Digital Sekolah Gema Nurani. Jurnal Ilmiah Sistem Informasi dan Teknik Informatika. Volume IX Nomor 1.

[7] Rahadian, H. \& Gandug Triyono. (2018). Rancangan Sistem Informasi Perpustakaan Pada SMAN 33 Jakarta Berbasis Object. Jurnal Idealis Volume 1 Nomor 5.

[8] Suharto, A. 2018. Analisa Evaluasi Sistem Informasi Manajemen Administrasi Akademik Dengan Metode Pieces Studi Kasus Pada Stmik Eresha. Jurnal Teknologi Informasi ESIT, 37-46.

[9] Wulandari, L., dkk. (2017). User Requirement Analysis For Digital Library Application Using Quality Function Deployment. Journal of Physic: Conf. Series 818 (2017) 012004. 